\title{
Inventory of armourstone
}

\author{
Valéry Le Turdu ${ }^{1, a}$, Marc Igigabel ${ }^{2, a}$, Sébastien Barlier ${ }^{1, a}$, Jean-Paul Masset ${ }^{1, a}$, Raphaël Bodet ${ }^{3, b}$, Mikaël Dumas ${ }^{4, c}$, Nicolas \\ Robert $^{5, a}$ and Bruno Berenger ${ }^{1, a}$ \\ ${ }^{1}$ Cerema, 23 avenue de l'Amiral Chauvin, BP 69, 49136 Les ponts de Cé, France \\ ${ }^{2}$ Cerema, Technopôle Brest Iroise, BP5, 29280 Plouzané, France \\ ${ }^{3}$ Union Nationale des Producteurs de Granulats, 3 rue Alfred Roll, 75849 PARIS CEDEX 17, France \\ ${ }^{4}$ Compagnie Nationale du Rhône, 4 rue de Chalon-sur-Saône, 69007 Lyon, France \\ ${ }^{5}$ Cerema, 151 rue de Paris, 02100 Saint Quentin, France
}

\begin{abstract}
Natural armourstone is widely used for hydraulic works, both in the coastal domain and in border of rivers and torrents, especially to protect against flood and the effects of waves and currents. To meet the expectations associated with this resource, an inventory of armourstone quarries was realized on a national scale in France. This inventory informs not only about the localization of quarries but also about the quality and the availability of materials. To fully optimize this inventory in a dynamic format, the association of all actors of the sector was preferred to archival research. This partnership approach led to project deliverables that can constitute durably a shared reference. The database can indeed be updated regularly thanks to the contacts established with the professionals of quarries. The access to this database is offered to a wide public: maritime and fluvial ports, local authorities in charge of planning and managing structures that protect against flood and other hydraulic hazards. This new database was organized considering its importance on the operational plan. This led to a hierarchical organization at two levels for each quarry face: first level, a synthesis sheet brings the essential information to realize choices upstream to the operational phases. Second level, a detailed specification sheet presents the technical characteristics observed in the past on the considered face. The atlas has two information broadcasting formats: a pdf file with browsing functions and a geographical information system that allows remote request of the database. These two media have their own updating rhythms, annual for the first and continue for the second.
\end{abstract}

\section{Introduction}

In recent years, a number of situations exist where the knowledge of armourstone resource was insufficient. It is not uncommon that these materials with a rough appearance, which seems to be easily accessible in many landscapes, appear finally, when projects are launched, to be the main source of difficulty for the conduct of operations. Either to localise quarries that may produce armourstone or to know more precisely characteristics of materials, knowledges of project owners and project managers are often very patchy and lead in design to technical and economic choices that are not optimized. In addition contexts in which armourstone are used also require to appreciate fairly accurately their availability: the conduct of operations in crisis following a major flood and the implementation of development projects cannot tolerate such uncertainties on the condition under which materials can be delivered.

One common reason for this lack of information is that armourstones are often a by-product for quarries, the main products being either aggregates or ornamental stones. Ordinarily, quarries operating mode is therefore turned to research specific characteristics for armourstone on well-defined periods, in response to specific requests. When answering to a tender request, two options are possible for quarries, sometimes in combination:

- operating an armourstone stock built up over time by blocks that did not fit in the manufacturing process of the main product,

- operating walls of a quarry with suitable extraction methods, in order to generate blocks that meet the criteria of desired size and integrity for the tender.

In the first case, armourstones are available relatively quickly, with the sorting and control operations. In the second case, the drilling and blasting will lengthen significantly the time required.

It was very crucial for us when we designed the database and the front-end Atlas to make sure we were taking in account the knowledge of this types of operational constraints at the scale of the quarry to manage in a better way the expectations of people in

a Corresponding author: valery.le-turdu@cerema.fr; marc.igigabel@cerema.fr; sebastien.barlier@cerema.fr; jean-

paul.masset@cerema.fr; nicolas.robert@cerema.fr; bruno.berenger@cerema.fr

b Corresponding author: raphael.bodet@unicem.fr

${ }^{\mathrm{c}}$ Corresponding author: m.dumas@cnr.tm.fr 
charge of the structure design and conducting operations, especially in an emergency context.

To produce a useful, shared and lasting Atlas in a dynamic format, the association of all the actors of the sector was preferred to an archival research. This desire to create a shared and sustainable reference founded the partnership approach adopted by Cerema and CNR (Rhône river National Company with quarries professional and the associations that represent them: UNPG (National Union of Aggregates Manufacturers) and CIGO (union of Independents Quarries from Great West) in particular.

\section{Objectives of the atlas}

The atlas (Figure 1) is designed to provide operational support to the optimal selection of armourstone.

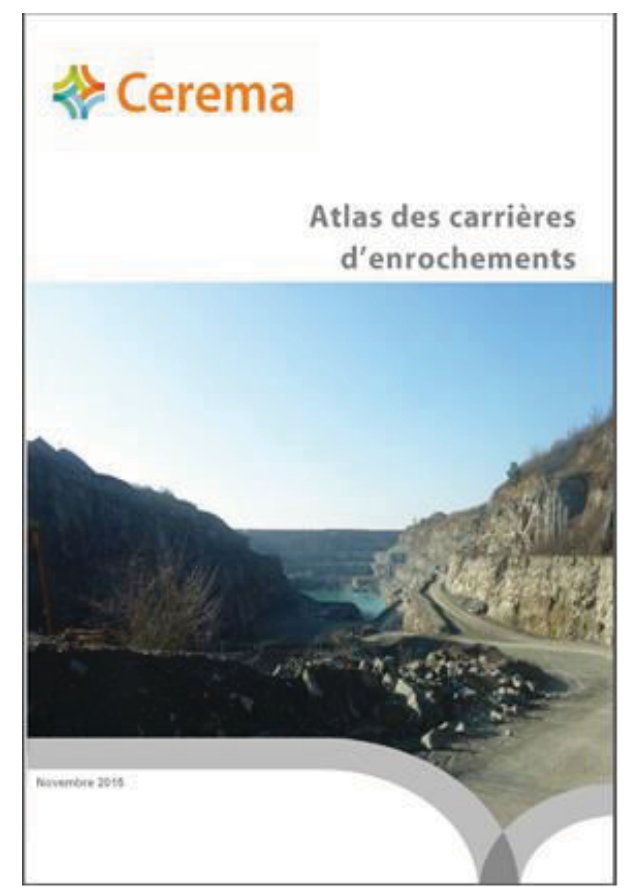

Figure 1. Cover page of armourstone quarries Atlas (Photo credit: the Lombardieres quarry Mousset (85)).

To this end, the atlas has two information levels that correspond to the preliminary study and to the project phase and the preparation of tender documents:

- first, the atlas localises armourstone quarries and it also indicates their production capacity and the potentially available stocks (based on historical data at 2 years and 10 years),

- secondly, the atlas aims at providing armourstone characteristics following criteria required by the standard specifications of NF EN 13383-1 (Table ZA.1). Nevertheless, we must be aware that these detailed specifications may vary depending on the state of operation in the quarry and therefore additional testing should generally be made on the already extracted material or on the working face before acceptance of armourstone. (this requires a quarry study to recognize the different facies and the delimitation of areas suitable for the production of armourstone).

In addition, the atlas of armourstone quarries takes advantage of the certification process by mobilizing auditors from Cerema. Inversely, the atlas is a way to encourage the certification, insofar as the publication can highlight this certification.

\section{Figures and tables}

\subsection{Principles}

Although the State decentralized services and the Cerema already had information about most of the quarries, these data had a good "degree update" only if they dealt with the petrographic nature of rocks or their intrinsic characteristics, that vary slowly. Conversely the information on the grading and integrity of armourstone and on the availability of blocks and the production capacity was insufficient, because more dependent on the progress in working faces. To update the information more regularly, the principle adopted was to get the information directly from quarries.

\subsection{Study protocol}

The objectives, methodology and funding plan of the study have been defined by Cerema in collaboration with the Ministry of Environment, Energy and Sea.

Cerema (laboratory of Angers) was in charge of undertaking the data collection, defining and creating the database structure and producing deliverables.

Workers quarries unions accompanied the project with their advices on the conditions of the partnership with quarries and established contacts. In the case of independent quarries not affiliated with a union, the laboratory of Angers exchanged directly. In all cases, to obtain reliable data, the laboratory of Angers offered to quarries technical assistance by phone. Following the treatment of transmitted information and before their final integration in the database, a validation phase was organized, so that each quarry could verify and approve the publication of its own data.

Over the period 2010-2014, Cerema and its partners engaged the professionals of quarry sector in a series of seven roundtables about armourstone to give the opportunity to learn about standards and, more generally, to discuss the state of the art. These roundtables have been used to gather information from quarry operators.

The organization of these roundtables was provided by the Cerema in partnership with:

- the workers quarries unions: the UNPG (National Union of Aggregates Manufacturers), SN-Roc (National Union of Ornamental Rocks) and CIGO (of Great West Quarries Independent union),

- CNR (Rhône river National Company).

The sites selected for the organization of panel discussions (see Figure 2) were defined to cover the entire metropolitan area and address the main 
armourstone use conditions (coastal areas, rivers and streams).

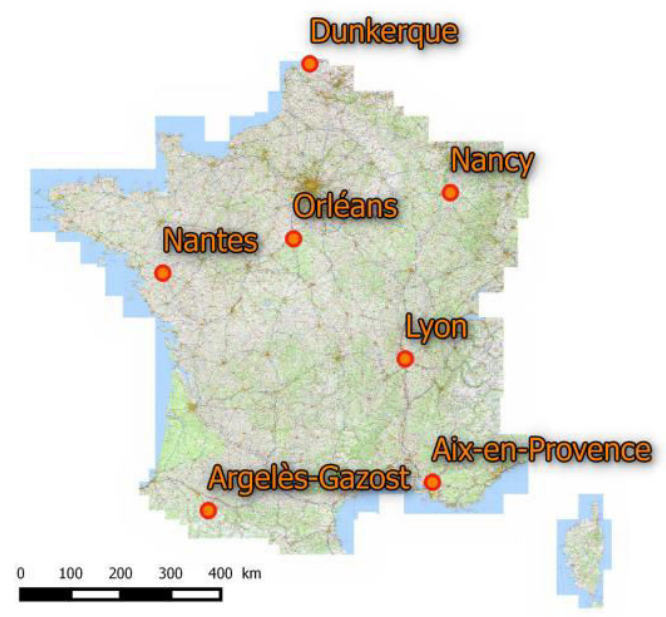

Figure 2. Location of roundtables.

The national conference on armourstone, held on October 27, 2015 in Paris (La Défense) in collaboration with the MEEM served as launch event for the armourstone quarries atlas.

\section{The atlas of armourstone quarries: a permanent and lasting link between manufacturers and users of armourstones}

\subsection{Organization of information: key features and detailed specification}

The essential characteristics have been identified and are the subject of sheets for each of the identified quarries (see Figure 3). The possibility is offered to a quarry to have several sheets if this quarry has several facies.

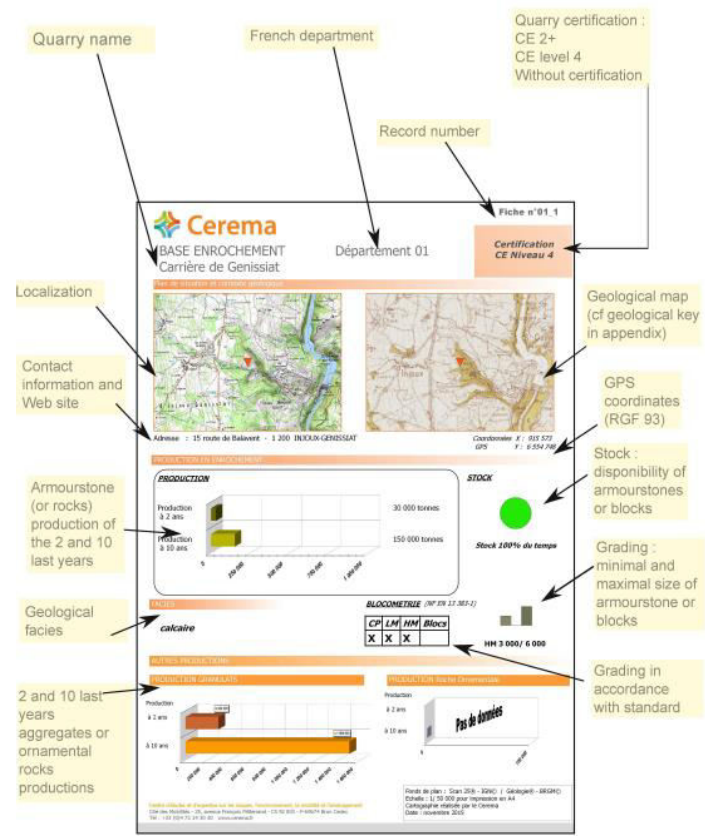

Figure 3. Example of sheet showing the essential characteristics.
Note that the production quantities of granulate or ornamental rock are indicated in the database. Indeed, these quantities give an idea of possible rock productions considering that:

-an aggregate quarry will never produce more than $20 \%$ of armourstone in tonnage compared to its production of aggregate. (This percentage may be zero in case of crushing all generated blocks.)

-an ornamental stone quarry can produce armourstone up to 10 times more than the ornamental rock quantity.

Others characteristics can be presented in detailed sheets (see Figure 4).

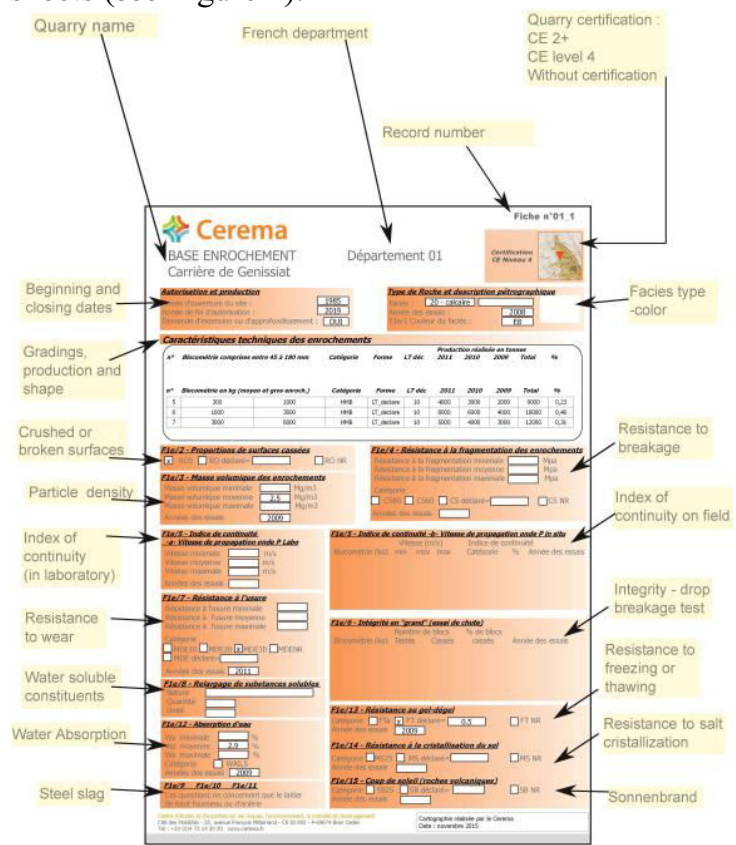

Figure 4. Example of detailed sheet.

This sheet contains characteristics required by the standard specifications (as described in the table ZA.1 of the standard EN 13 383-1):

-simple indication of the petrographic type,

-shape: length to thickness ratio,

-armourstone grading,

-particle density,

-resistance to breakage,

-resistance to attrition (for armourstone used as top layer that will be subject to abrasion due to sediment),

-percentage of crushed or broken surfaces (in the case the presence of rounded rocks could cause instability of the structure),

-water soluble constituents (if appropriate, test results should be judged according to local regulations),

-requirement associated with grouting (if clay or earth exist on the surface of armourstone that need to be sealed with bitumen or mortar),

-durability against freeze/thaw (if applicable, in areas subject to freezing), 
-durability against salt crystallization (if applicable, in hot climates and in parts of structures subject to significant variations in the degree of salt water saturation),

-durability against "sonnenbrand" (in case of doubt, where signs of "sonnenbrand" are possible),

-durability against disintegration of air-cooled blastfurnace slag and steel slag (if applicable).

Note that:

-integrity is not required by standard tests (not required quantification) but essential to the sustainability of structures. To account for this parameter, the database includes sections on the index of continuity (based on the measurement of acoustic velocity) and the "great integrity" (based on the drop test),

-the color of the stones has no standardized test. However in some situations (landscape integration in classified site) this criterion can be a determining factor in the selection of armourstone. Therefore, the atlas allows quarries to describe the armourstone color.

Regardless of the data type, it is very important to make sure the date is recorded precisely. The possibility to access a datum at multiple dates is also interesting: it allows to assess the stability of the production.

\subsection{The information dissemination media}

The database managers decided to make two evolutionary formats coexist:

-a reference book, published periodically (presumably annually), freely downloadable and printable [1],

-a geographic information system that can be updated anytime and on which it is possible to make computing requests [2].

\section{Conclusions}

The atlas of armourstone quarries, through the historical view on production and stockpiles it provides and by the rapid contact with quarry operators it allows, is a tool designed to help at any time crisis or project manager in decision making:

-at the design stage (adapting the design to the actual available resources),

-in the procurement (a better knowledge of available stocks limits the award of contracts to quarries that cannot supply a sufficient amount of armoustones in compliance with specifications, a situation that constraints to search as a matter of urgency for alternative supply sites).

\section{References}

1. Atlas download site: http://www.eau-merfleuves.cerema.fr/atlas-des-carrieres-denrochements-a1363.html

2. Consultation Website of the database http://cartelie.application.developpementdurable.gouv.fr/cartelie/voir.do?carte=Carriere Enrochement\&service $=$ CEREMA

\section{Acknowledgments}

The study was funded by the MEDDE.

Authors thank quarries professionals for transmitting data and for the confidence they placed in the processing and dissemination of information. 